\title{
PALEOINTENSIDADE DO CAMPO MAGNÉTICO TERRESTRES NO PROTEROZÓICO
}

\author{
Klaydson Reinaldo Celino \\ Orientador: Dr. Ricardo Ivan Ferreira da Trindade (IAG-USP) \\ 109 p. - Dissertação (Mestrado) - Defesa 12.04.2007
}

RESUMO. A idade de formação do núcleo interno sólido é ainda motivo de controvérsias. As estimativas, baseadas em modelos geoquímicos ou termodinâmicos, variam desde o Arqueano até 0 início do Cambriano. Os dados de paleointensidade poderiam servir como evidência experimental para este processo, uma vez que a estratificação do núcleo interno resultaria no início da conveç̧ão composicional. No entanto, a atual base de dados de paleointensidade absoluta para o Arqueano e o Precambriano é ainda bastante limitada, apresentando menos de 50 determinações entre 3,50 e 0,50 Ga. Nesta dissertação experimentos de paleointensidade absoluta foram conduzidos em amostras de duas unidades aflorantes no Cráton Amazônico: a suíte Colider (1,80 Ga) e a formação Nova Floresta (1,20 Ga). As duas unidades são caracterizadas por componentes magnéticas estáveis, reveladas após desmagnetização AF e térmica. No entanto, as amostras da suíte Colider apresentaram forte alteração magnetomineralógica durante os ciclos de aquecimento, de modo que as 30 amostras submetidas ao protocolo de duplo aquecimento tipo Thellier não forneceram resultados satisfatórios. A formação Nova Floresta apresentou curvas termomagnéticas reversíveis, sendo a magnetita com estrutura de domínio multidomínio a domínio simples o principal portador magnético. Nessas amostras, os experimentos de duplo aquecimento tipo Thellier foram combinados com desmagnetização a baixas temperaturas. Esse protocolo de medidas permitiu recuperar o campo antigo com sucesso em $25 \%$ das amostras. Os valores de paleocampo para os gabros de Nova Floresta variam entre 2,44 e 7,23 $\mu \mathrm{T}$ (média de 5,02 $\pm 1,45 \mu \mathrm{T}$ ); a única estimativa de sucesso obtida nos basaltos forneceu um paleocampo mais alto de 18,32 $\mu$ T. Esses resultados correspondem a um VDM médio de 1,47 $\pm 0,92 \times 10^{22} \mathrm{Am}^{2}$, aumentando 0 número de valores de campo baixo que dominam a base de dados do Precambriano. As estimativas sugerem uma evolução gradativa do campo magnético terrestre, corroborando os modelos termodinâmicos mais recentes, e exemplificam a necessidade de abordagens alternativas no estudo de rochas antigas.

ABSTRACT. The age of solid inner core growth is still a matter of debate, with estimates varying from the Archean up to the beginning of Cambrian times. Experimental evidence or this process may be derived from the evolution of the Earth's field paleointensity, since the onset of solid inner core induces compositional convection and tend to stabilize the geodynamo. Yet, paleointensity data for the Archean and the Precambrian are still very scarce, with less than 50 determinations between 3.50 and $0.50 \mathrm{Ga}$. In this work we have conducted double-heating Thellier paleointensity experiments on two mafic volcanic and intrusive units from the Amazon Craton with ages of $1.80 \mathrm{Ga}$ (Colider suite) and $1.20 \mathrm{Ga}$ (Nova Floresta formation). Both units have shown very stable magnetic components after AF and thermal demagnetization. Magnetic mineralogy for the Paleoproterozoic Colider suite reveals strong magneto-mineralogical changes during heating thus hindering successful paleointensity estimates. The Mesoproterozoic Nova Floresta samples do not shown significant alteration during heating; magnetic carriers being magnetite in single to multi-domain states. Addition of low-temperature demagnetization to the Thellier protocol in Nova Floresta samples, reducing the effect of multi-domain grains, allowed the recovery of the ancient field for $25 \%$ of the samples. Paleointensity values for Nova Floresta gabbros vary between 2.44 and $7.23 \mu \mathrm{T}$ (average of $5.02 \pm$ $1.45 \mu \mathrm{T}$ ); the only estimate for basalts give a higher paleointensity of $18.32 \mu \mathrm{T}$. These results correspond to a mean virtual dipole moment (VDM) of $1.47 \pm 0.92 \times 10^{22} \mathrm{Am}^{2}$, thus increasing the low field estimates for the Precambrian. Our results reinforce the idea of a gradual increase in Earth's field intensity in agreement with recent thermodynamic models. It also exemplifies the need for alternative methods to estimate the paleointensity of ancient rocks. 